\title{
Training of the Information Professional: Reflections from Studies of Graduates
}

\author{
Asa Fujino $^{1}$, Adaci Aparecida Oliveira Rosa da Silva ${ }^{2, *}$ \\ ${ }^{1}$ 0000-0003-0652-5222 + Universidade de São Paulo, Brasil, São Paulo. asfujino@ usp.br \\ 2,* 0000-0002-5015-6084 + Universidade de São Paulo,Brasil,São Paulo. \\ adaci.cruz@gmail.com
}

Keywords: Information Science; graduates; library; Brasil

\section{Introduction}

The understanding of the issues that affect the training of information professionals and documentation require reflections on the impact of information technological dynamics, Digital Technologies of Information and Communication (TDIC) at the world of work, altered by the movement of rupture of the space/time notion (Giddens, 1991), and cross jurisdictions and professional boundaries (Abbott,1988), where pedagogical dilemmas come upon qualification for these professions considering future prospects.

Saracevic (1996, p. 60) notes that theoretical and methodological contributions of Information Science made possible the understanding of "a long list of problems, processes and structures associated with knowledge, information and human behavior in the information", however, in view of the immeasurable amount of data waiting for organization and interpretation (Barreto, 1998), training for the development of professional skills associated with informational issues becomes challenging.

The studies of "systematic literature review" on a given topic are fundamental to elicit promising trends and simultaneously reveals overcome aspects. They establish mappings at the theoretical and methodological levels, based on an integrative synthesis, which can either point out their fragilities, or give support to their constructs for the recognition of a field of studies; and, constitute an empirical object, for gathering in the results of research published in different scientific communication vehicles. It is up to scientific research to explore ways to help qualify alternatives and trends in possible solutions, by identifying in the dynamics of the field of Information Studies what they impose on education and the world of training for work.

Thus, studies based on "studies of graduates or egresses" are instruments in obtaining subsidies for evaluation of the educational system, undergraduate and postgraduate, as to the repercussion of political-pedagogical projects in academic and professional training and career development. In this study, it is considered "graduates or egresses", in college degree at the postgraduate level strictu-sensu (Pena, 2000). 
In other countries, researchers about studies of graduates are often subsidized by higher education institution, with characteristic and differentiated objectives, such as France, England and United States. The focus on institutional assessment for improvements in institutional management and policies related to education; for actions of accreditation and rendering of accounts, as well as for raise funds from donations (Nishimura, 2015). However, Brazilian institutions do not follow "this tradition of accompanying or relating to their former students" according to Cassimiro and Pereira (2006, quoted by Nishimura, 2015, p. 12).

In Brazil, the Information Science area brings together college and researchers, research groups, graduate programs in Information Science and undergraduate programs in the areas of Library Science, Archives, Museology, Documentation and Information Management (Araújo, 2014). In this context, there is interest in the study of graduates with research oriented and performed by students, but with independent proposals without sponsoring departments or institutions for extensive research. In this way, it is considered that their systematization can contribute to the understanding of this complex phenomenon, besides contributing to the diagnosis of the training of these professionals against the demands of the contemporary labor market, helping in the progression of research in information, education and work.

In the formative scope, the studies of graduates start from the presupposition of the necessity of Education formation professional and, through them, the get subsidies to assist in the identification of problems/needs when the professional practice. The analyzing the results of studies graduates, for the improvement of vocational training, it is important correlation will them to the education program and curriculum where the study takes place, the proposals of curriculum guidelines and current stage to the understanding class associations about the profession, as problems/deficiencies can during the mismatch between training and the requirements of the labor market or reflect the priorities imposed by the pedagogical project of the training program, which, could be, was not understood by the respondents of these surveys.

However, in the moment the research, the main objective was to find results in the studies of graduates promoted in postgraduate and undergraduate courses in Information Science and Librarianship, considering the sources of information for the evaluation of the educational quality and reflections in the work world of their alumni, and to note whether they point so much the demands of the profession, how to improve the training, order to answer the question: the demands indicated in the studies of graduates are in line with studies of Education and Training, the guidelines National Curriculum (DCN) and the regulatory actions of the Council Professional Librarianship (CFB)?

\section{Methodology}

The study was based on the identification of the studies that deal with the theme "Studies of Graduates" published in Information Science journals on their associated areas, in the Brazilian context. The articles were collected in the Reference Database of Periodicals in Information Science (BRAPCI), through the descriptor "egresses or graduates". It was 
considered the period from 2000 to 2018 , considering the interest in the critical moment of the analysis and prospects for the future of the professions.

In the search for the term "graduates" found 45 articles. The post reading the summaries were eliminated 27 articles, because they have not compatible with the goals of study, such as: indicators scientific; application of management models and fields of study such as Management and Engineering, and prospecting studies with contributions to "future and potential graduates" of a certain area.

In structuring the review, articles are framed as "study graduates" were distributed by areas, in order to point out the impact. Were selected 18 articles , being: 10 of Librarianship; one of the Archivology; five Postgraduate CI, and two in Information Management at the levels of undergraduate and graduate studies. No studies of the Museology area were retrieved.

To delimit the sample in the 10 articles of the librarianship, in approximation of the proposal of comparative analysis between its results and the elements that structure the university formation and the professional exercise, such as: the Proposals of the DCN, the critical analysis of the academic area of Information Science Studies on education and vocational training (educational projects and curriculum) and the guidelines of the class councils. Data analysis was performed from the qualitative perspective, considering that the data collected are descriptive and the objective is to verify how the problem is manifested (Creswell, 2007).

The analysis parameters are in line with the guidance of Rodrigues (2012, p. 16) so that "the basis of a profession consists of three components: training (education system), Professional Practice and research", criteria these elected by Martha Dosa, cited by Muller (1989) and Guimarães (2004), in your studies on the training of information professionals in such a diverse area.

Barbosa, Carvalho e Cunha (2017) to argue go to training librarian, from the analysis of curriculum frameworks, the minimum curricula under the purpose of the contents changed in 1962 and 1982, and the subsequent perspective of skills and abilities derived by DCN ( Council National Education [CNE], 2001), noted the difficulties in reshaping a curriculum proposal, although supported by the flexibility provided by DCN, in line with the critical Souza (20012012) on the uncertainty of the area over the professional that is intended to form.

In the field of education and research, Rodrigues (2012, p. 16) emphasizes the importance of research as a propellant of educational practice and of the educational system supported by scientific parameters, which would allow a "practice with greater scientific competence and social legitimacy in the field professional"; while, Barros, Cunha and Café (2018, pag. 305) warn that "those responsible for the creation and maintenance of Librarianship courses must be attentive to the increasingly diverse demands of society" on the need to adapt the professional profile to the pedagogical projects and curriculum structure of the universities. 
Another impact element on the orientation of policies and institutional and social practices on professional field are the associations and class councils. The profession of librarian is regulated in the country and the Federal Library Board (CFB) has historically taken a position on librarianship teaching models, as in the recent discussion on higher education provision in the distance education mode online (EAD), covering traditional curriculum models ( $\mathrm{CFB} / \mathrm{CFB}$ agreement/CAPES, 2009), and other times proposing restrictive measures to educational institutions, such as the recommendations on supervised internships (CFB, 2017). Barros et al. (2018, p. 292), on the other hand, point to "the distance of the board professionals' librarians discussions on the demands for the formation of the librarian, as these associations are representatives of these professionals in the workplace".

\section{Results and Discussion}

From the survey sample, the 10 selected articles were categorized according to reflex of graduates of their training, the possible paths indicated by the research on the experience of education, professional practice and the labor market. The categorization followed the structure of the DCN: profile; skills and abilities; curriculum and activities and training; and structure and evaluating institutional.

The studies involved 13 elements, of which 10 were federal public universities: Amazonas (UFAM); Pará (UFPA); Maranhão (UFMA); Alagoas (UFAL); Bahia (UFBA); Minas Gerais (UFMG); Santa Catarina (UFSC); São Carlos (UFSCar); Rio Grande (UFRG), and Rio Grande do Sul (UFRGS); Two: University of São Paulo, Capital and Ribeirão Preto (USP-RP), and Paulista State University (UNESP-Marília); And one confessional: Pontifical Catholic University (PUC-Campinas). The oldest class of graduates cited is from 1996 and the most recent is from 2017. The articles were published between 2000 and 2018, two of which are from a master's degree (USP-RP; UFSC/UFAM/UFPA) and one is in the data collection phase in UFAL.

A predominance of studies aimed at the identification of graduates (gender, age group, employment and workplace) was predominant; salary was focused on a few aspects; and there were no questions about cultural habits or perceptions about changes in the world of work. Ferreira, Veiga, Teixeira, and Evangelista (2013) observed the in the UFMA survey that "old problems persist as inequality between classes, specialization of functions, list of genres and especially the notorious absence of class entities for the effective consolidation of the professional in relation to their salary", highlighting the need to acting on differences regional toward the south-southeast axis in the country.

The results of questions related to the employability and employment indicated that the absorption rate in the labor Market reaches about $90 \%$ in the first year formed from UFMG. Santos, Mosque, Neves and Bastos (2016), they related that analysis in the model proposed by Valentine (2000) which ranks the informational market: (i) traditional; (ii) trends; (iii) existing and little busy, and concluded that the professionals are concentrated in the traditional market 
of university libraries, away from the demands of the virtual information market. To Faria and Castro (2014, p. 59), in the study with 209 graduates of three public universities in São Paulo (USP-RP, UNESP and UFSCar)", the share of professionals working with information technology in the 'trend information market' is restricted"; situation that "there is a big potential labor market" and remind that "is necessary to expand the range of possibilities that go beyond the traditional intelligence units", according to the guidelines of the DCN.

On the "existing and unoccupied market", Fujino and Vasconcelos (2011) assessed contributions the stage for academic and vocational training graduates USP and found that access to new virtual work spaces constitute themselves in defiance of the trainees due to the conflict between the pedagogical autonomy of the universities and the demands of the Professional Council regarding the supervision of student in the grantor, despite the orientation of the DCN that places the curricular stage under the immediate responsibility of the teacher. The authors point out the need to review pedagogy contents of this discipline as basis to improve the education and training in line with the guidelines that treat the stage as "privileged instrument to link performance and content systematically and permanently" (CNE, 2001). However, internship activities are rarely mentioned as mechanisms evaluation in the education program or curriculum, and while important source on the performance and qualification of the student in society provides by the training institutions.

The dimension of the academic formation was evaluated by the compatibility of disciplines with the requirements of the Labor Market and the satisfaction of graduates with the course and profession. Silveira and Gonçalves (2009, p. 134) concluded that "in the contents indicated by the graduates (UFRG) the most important ones for the professional life appear in the most technical disciplines and that characterize the course of Librarianship" [Emphasis added], it is worth noting that the respondents indicated with less relevance the disciplines: languages; marketing, statistic; sources of information and informatics, moving against the flexibility proposed by the DCN, adopted from 2002.

In contrast, Beraquet, Ciol, Santos, and Stefani (2002), notes that the market for the graduates of the PUC-Campinas demanded professionals with managerial skills; of coordinates working groups, and despite the satisfaction of graduates with the course, suggested offering general training courses on socio-political and cultural aspects; Foreign languages and information technology, in line with the guidelines set forth in the recent DCN, regarding the training of professionals capable of facing the challenges of the contemporary world. Kruel et $a l$, in 2000, also sought to associate the future demands arising from the international market with innovations in intellectual and technological tools and that could be assimilated in a new curricular project for the course at UFRGS.

Its can be observed to remain in the understanding of the profession from the traditional functions and practices, and the workspaces focused on libraries. In the meantime, studies by Cunha (2012); Santos and Barreira (2014), and especially Faria and Castro (2014) present attempts at terminological and conceptual adequacy in the studies of graduates, considering the 
NCDs and the flexibility provided to universities courses as to the suitability of the curriculum contents and structure of the courses the social demands.

\section{Conclusions}

We conclude that the process has been forwarded by isolated initiatives, and that the public debate, involving university and society, education, research, and the professional world requires actions to build dialogue, which may result in the definition of projects pedagogical and curriculum adapted to the demands of the graduates in their regions of origin and demands of the world of work.

Although several studies of alumni point to the need for university to observe the demands of society and the vacuum in virtual environments not occupied by professional librarians, and the DCN aim to flexible and update curricula and contents to bring teaching and research closer to the world of work, there was the gap between university and board professional discussions, especially with regard to the role of internship and distance education in professional training to the world of contemporary work, especially the Virtual. Because It is a regulated profession, but strongly dependent on changes in the world of work, it is suggested an effort to build a space for discussion that brings together researchers, teachers, associations and professional advice.

\section{References:}

Abbott, A. (1988). The system of professions: an essay on the division of expert labor. Chicago, IL: The University of Chicago Press.

Araújo, C. A. A. (2014). Arquivologia, Biblioteconomia, Museologia e Ciência da Informação: o diálogo possível. Brasília, DF: Briquet de Lemos.

Araújo, N. C., \& Gomes, M. A. (2018). Egressos do curso de Biblioteconomia da Universidade Federal de Alagoas de 2003 a 2017 aonde estão?. Anais do Encontro Nacional de Pesquisa em Ciência da Informação, Londrina, PR, Brasil, 19, 4143-4148. Disponível em 〈http://www.brapci.inf.br/index.php/res/v/102337>

Barbosa Neto, P., Carvalho, L., \& Cunha, J. (2017). Curso de Graduação em Biblioteconomia da UFRN: proposta metodológica para sua reformulação. Revista Informação na Sociedade Contemporânea, 1(2), 1-23. Disponível em <https://periodicos.ufrn.br/informacao/article/view/11579>.

Barreto, A. A. (1998). O mercado de informação no Brasil. Transinformação, 10(2), 55-67. DOI: $10.5433 / 1981-8920.2000 v 5 n 1 p 25$

Barros, C. M., Cunha, M. F. V., \& Café, L. (2018).Estudo comparativo dos currículos dos cursos de Biblioteconomia no Brasil. Informação \& Informação, 23(1), 290-310. DOI: http://dx.doi.org/10.5433/1981-8920.2018v23n1p290. 
Beraquet, V. S. M., Ciol, R., Santos, M. L. K.,\& Stefani, R. C. (2002).Qualidade e avaliação curricular em Biblioteconomia: perspectivas de docentes, egressos e empregadores. Cadernos BAD (Portugal), 1. Disponível em http://www.brapci.inf.br/index.php/res/v/70498.

Conselho Nacional de Educação (2001). Parecer CNE/CES N. 492/2001, de 3 de abril de 2001. Apresenta Diretrizes Curriculares Nacionais dos cursos de Filosofia, História, geografia, Serviço Social, Comunicação Social, Ciências Sociais, Letras, Biblioteconomia, Arquivologia e Museologia. Diário Oficial da União, Seção 1e, p. 50. Disponível em http://portal.mec.gov.br/cne/arquivos/pdf/CES0492.pdf.

Conselho Federal de Biblioteconomia. (2009).Ensino a distância: assinado acordo de cooperação técnica entre UAB e CFB. Boletim eletrônico do Sistema CFB/CRB, Brasília, $D F$, Ano 2, Especial. Disponível em http://repositorio.cfb.org.br.

Conselho Federal de Biblioteconomia. (2017). Resolução n. 192, de 12 de dezembro de 2017. Dispõe sobre orientação e supervisão de estágio. Diário Oficial da União. Brasília, Seção 1, p. 203. Disponível em http://repositorio.cfb.org.br/handle/123456789/1306.

Creswell, J.W. (2007). Projeto de Pesquisa: metodologias qualitativo, quantitativo e misto. Porto Alegre, RS: Artmed.

Cunha, G. A. (2012). Perfil do bibliotecário da região norte: estudo dos egressos da Universidade Federal do Amazonas e Universidade Federal do Pará referente ao período de 2005 a 2010. Encontros Bibli: Revista Eletrônica de Biblioteconomia e Ciência da Informação, 17(35). Disponível em http://www.brapci.inf.br/index.php/res/v/31394.

Faria, A. C. C., \& Castro, C. M., F F $^{\mathbf{2}}$ (2014).Profissional da informação: estudo dos egressos no estado de São Paulo, mundo do trabalho, habilidades e competências. Ponto de Acesso 8(3), 44-63. Disponível em http://www.brapci.inf.br/index.php/res/v/81388.

Ferreira, M. M.; Veiga, M. A. P.; Teixeira, R. P., \& Evangelista, R. L. (2013). As relações de classe e de gênero no mercado de trabalho do profissional bibliotecário no estado do Maranhão. Múltiplos Olhares em Ciência da Informação, 3(2). Disponível em http://www.brapci.inf.br/index.php/res/v/62209.

Fujino, A., \& Vasconcelos, M. O. (2011). Estágios: reflexões sobre a ação didáticopedagógica na formação do profissional da informação. CRB8 Digital, 4(1). Disponível em http://www.brapci.inf.br/index.php/res/v/9686

Giddens, A. (1991). As consequências da modernidade. Tradução de Raul Filker. São Paulo, SP: UNESP.

Kruel, I. R. P.; Ferreira, G. I. S.; Tazima, I. H.; Scharnberg, J. M. R.; Bonotto, M. E. K. K.; Laan, R. H. V. D. (2000). Mercado de trabalho do bibliotecário em Porto Alegre. Revista de Biblioteconomia \& Comunicação, 8(1). Disponível em http://www.brapci.inf.br/index.php/res/v/99834

Nishimura, A.T. (2015). Avaliação de programas de doutorado em Administração sob a perspectiva dos egressos. (Tese de Doutorado). Universidade de São Paulo. São Paulo, SP, Brasil. Disponível em http://www.teses.usp.br 
Pena, M.D.C. (2000). Acompanhamento de egressos: análise conceitual e sua aplicação no âmbito educacional brasileiro. Educação e Tecnologia. 5(2), 1-12.

Rodrigues, M. E. F. (2012). A pesquisa no ensino de graduação e a articulação com a pósgraduação na Ciência da Informação: reflexões e proposições. Ponto de Acesso, 6(2), 3-20. Disponível em https://portalseer.ufba.br/index.php/revistaici/article/view/6099/0

Santos, J. O., \& Barreira, M. I. J. S. (2014).Perfil do bibliotecário baiano: um olhar sobre as décadas de 1980 a 2012. Páginas A\&B, Arquivos e Bibliotecas, 1, 46-162. Disponível em http://www.brapci.inf.br/index.php/res/v/65710

Santos, P. R., Mesquita, J. M. C., Neves, J. T. R., \& Bastos, A. M. (2016). Inserção no mercado de trabalho e a empregabilidade de bacharéis em Biblioteconomia. Perspectivas em Ciência da Informação, 21(2), 14-32. Disponível em http://www.brapci.inf.br/index.php/res/v/36054

Saracevic, T. (1996).Ciência da informação: origem, evolução e relações. Perspectiva em Ciência da Informação, 1(1), 41-62. Disponível em http://portaldeperiodicos.eci.ufmg.br/index.php/pci/article/view/235/22

Silveira, J. P. B., \& Gonçalves, R. B. (2009). Perfil dos egressos do curso de Biblioteconomia da Universidade Federal do Rio Grande (1998-2007). BIBLOS - Revista do Instituto de Ciências Humanas e da Informação, 23(2), 127-135. Disponível em http://www.brapci.inf.br/index.php/res/v/22966

Souza, F. C. (2001). Formação de Bibliotecários para uma sociedade livre. Encontros Bibli: Revista de Biblioteconomia em Ciência da Informação, 11(6), 39-51. Disponível em https://periodicos.ufsc.br/index.php/eb/issue/view/31

Souza, F. C. (2012). A contribuição da ABEBD para a configuração política e ideológica das Diretrizes Curriculares Nacionais [DCN] do Curso de graduação em Biblioteconomia implantadas a partir de 2001. Florianópolis: UFSC. Relatório de Pesquisa. Disponível em <http://eprints.rclis.org/19807/>

Valentim, M. L. P. (2000). O moderno profissional da informação: formação e perspectiva profissional. Encontros Bibli: revista eletrônica de Biblioteconomia e Ciência da Informação, 9(5), 16-28. Disponível em https://periodicos.ufsc.br/index.php/eb/article/view/1518-2924.2000v5n9p16 